\title{
Highlands Malaria is Common but HIV very rare in Rural Areas of Burundi 2,000 Meters above Sea Level (Short communication)
}

\author{
G. Ngamygamie (Gaston Ngamygamie)'1, E. Smrekova (Eva Smrekova)1 , V. Krcmery

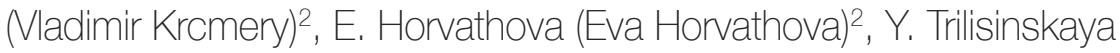 \\ (Yoanna Trilisinskaya) ${ }^{1}$, K. Mulama (Katrina Mulama) ${ }^{1}$
}

${ }^{1}$ Centre de Sante Rumeza \& Hospital of Buraniro, Carmelitan Sisters, joint program with SEU Tropical Institute \& St. Elizabeth University Tropical Program in Republic of Burundi.

${ }^{2}$ Slovak Medical University SZU, Dept. of Tropical Medicine \& Dept. of Public Health \& Alergy Center Vienna West, Vienna, Austria.

\section{E-mail address:}

smrekovaeva@yahoo.fr

\section{Reprint address:}

Eva Smrekova

Centre de Sante Rumeza

Rep of Burundi

Source: Clinical Social Work and Health Intervention

Volume: 12

Issue: 1

Pages: 54 - 55

Cited references: 2

\section{Reviewers:}

M. Johnson Mawole

Mukuru, Nairobi

Vitalis Okoth

School of Public Health University of Hargeisa

\section{Publisher:}

International Society of Applied Preventive Medicine i-gap

\section{Keywords:}

Highlands Malaria HIV.

CSWHI 2021; 12(1): 54 - 55; DOI: 10.22359/cswhi_12_1_11 CC Clinical Social Work and Health Intervention

\section{Abstract:}

Highlands malaria is defined as falciparum parasitaemia at 1,500 meters above sea level nowadays above 2,000 meters. Here we describe the relatively high proportion among outpatients in rural Burundi with a low density of population and travel mobility leading to minimal occurrence of HIV and TB. 


\section{Introduction}

50 years ago, malaria was endemic up to 1,500 $\mathrm{m}$ above sea level, however with urbanization. climate changes and global warming, it is now clinically defined as parasitaemia at an altitude of 2,000 $\mathrm{m}$ above sea level. In the last 5 years, we have described malaria in the rural population of Rwanda at an altitude of 2,500 sea level altitude(1). Vice versa, the proportion of HIV is decreasing in those highlands because climate and the absence of agriculture has decreased the density and contact resulting in a logical decrease in sexually transmitted diseases including HIV(2). This short pilot research showed a decreasing occurrence of HIV in the presence of increasing highlands malaria in the Burundian Region of Rumeza at the altitude of 2,000 m above sea level in 2020 .

\section{Patients and Methods}

A single cohort of outpatient visits within one month at the Rumeza Healthcare Center serving the rural area of about 10,000 people showed 198 visits in the month of October. This clinic is between 1,950 and 2,100 meters above sea level with next nearest hospital is about a 1 hour drive so most of the patients are managed on an outpatient basis.

\section{Results and Discussion}

Malaria was the second commonest disease, surprisingly responsible for up to $30 \%$ of all admissions, just after upper and lower respiratory tract infections (41\%); third commonest disease was gastroenteritis with $19 \%$ of all visits. Parasites were surprisingly found at a much lower proportion than in large cities e.g. Nairobi (2) within a screening for anemia of $7 \%$. Only 4 patients with TB and only 2 patients with HIV positive tests were diagnosed. Low mobility and low density of population were considered responsible for an unexpectedly low occurrence of HIV and $\mathrm{TB}$, vice versa, very surprisingly was a $30 \%$ proportion of fever epidosed with microscopically and repid test-confirmed malaria due to $\mathrm{P}$ falciparum.

\section{Conclusions}

In conclusion, highlands malaria is an emerging public health problem also at altitudes of more than 2,000 meters and stand by therapy spe- cially for children should be included into the first aid equipment available in all villages irrespective of altitude. Our findings are similar to those 5 years ago in Rwanda in the Bigugu Region near the Lake of Kiwu, at an altitude up to 2,500 meters with similar morbidity. Surprisingly, the proportion of HIV was only $1 \%$ and TB $2 \%$ that is much lower than in other Eastern African Union countries such as Uganda, Tanzania and Kenya.

\section{References}

1. MASAN J, SRAMKA M, SABO A, KALATOVA D, ROTTERMUND J, RUZICKY E (2020) The covid-19 disease situation prior to October 2020 in selected countries: the potentially severe consequences of Covid-19 on the nervous system and several key solutions to Covid-19 in relation to digitization and artificial intelligence. In: Acta Misiologica / Bucko Ladislav. - ISBN 2453-7160. - Vol. 14, no. 2 p. 112-126.

2. PERI H A, SUBRAMANIAN S, SLADECKOVA V, BYDZOVSKY J, DURCOVA B, KUBALIKOVA Z, OLAH M, MATULNIKOVA L, DOKTOROV A, BERESOVA A, KUBIK F, FULA M, OTRUBOVA J, KALATOVA D, KUKUCKOVA E, JURINOVA S, BENCA J, SHAHUM A, HOY LEANG HOINAND CHENG HOIN, SETA S/ Early detection of adverse therapy reaction in orphan children with AIDS (short communication) / In: Acta Missiologica. ISSN 1337-7515. - Vol. 13, no. 2 (2019) p. $184-187$. 